Jurnal Administrasi Publik (Public Administration Journal), 11 (2) December 2021 ISSN 2088527X (Print) ISSN 2548-7787 (Online), DOI: 10.31289/iap.v11i2.5760

Jurnal Administrasi Publik (Public Administration Journal)

Available online http://ojs.uma.ac.id/index.php/iap

\title{
Effectiveness Level of Regional Original Revenue, Urban Buffer, and Rural Areas
}

\section{Fajar Novriansyah*, Maulana Mukhlis, Pitojo Budiono \& Syarief Makhya}

Master of Government Science, Faculty of Social and Political Sciences, Universitas Lampung, Indonesia.

Received: August 30, 2021; Reviewed: August 31, 2021: Accepted: September 22, 2021

* Corresponding Email:mfajarnovriansyah@gmail.com

\begin{abstract}
This study aims to analyze and determine the level of effectiveness of regional revenue. The study was conducted in Bandar Lampung City, Pringsewu Regency, and Mesuji Regency. This study used secondary data, which were analyzed by quantitative descriptive method. Secondary data were obtained from the regional budget reports for Bandar Lampung City, Pringsewu Regency, and Mesuji Regency, which had been processed and analyzed. To solve this problem, use the effectiveness ratio formula in analyzing the effectiveness of regional revenue receipts. The results in this study indicate that the level of effectiveness of regional original revenue (PAD) in Bandar Lampung City, Pringsewu Regency and Mesuji Regency in 2016-2019 was fluctuating. Pringsewu Regency and Mesuji Regency had an average regional original revenue effectiveness ratio in the last four years, including the effective category, while Bandar Lampung City in the last four years was in the less effective category. This study concludes that the effectiveness of regional revenue in Bandar Lampung City, Pringsewu Regency, and Mesuji Regency has an unstable regional original revenue since it has increased and decreased. The effectiveness level does not affect the contribution given to regional revenue.
\end{abstract}

Keywords: Effectiveness; Regional Original Revenue

How to Cite: Novriansyah, M.F, Mukhlis, M., Budiono, P., \& Makhya, S. (2021). The Effectiveness Level of Regional Original Revenue, Urban Buffers, And Far from The City. Journal of Public Administration (Public Administration Journal). 11(2):197-205 


\section{INTRODUCTION}

The implementation of regional autonomy causes the regions to have an obligation to find solutions and decide how to decide a policy that will impact regional revenues and budget management to run the government. The optimization carried out by the regional revenue management work unit must increase regional revenue (PAD) and another financing for the sustainability of government activities (Rahmayati, 2016). The decentralization system, which is the embodiment of regional autonomy, requires regions to solve their problems and obtain and manage funds to carry out their government activities. The failure of the decentralization policy is due to the low regional revenue compared to the total revenue (Sriyana, 2009).

In the area of regional revenue management, regional governments always focus on efforts to increase PAD revenues. To realize it, one of the efforts to increase PAD is tax extensification and intensification; it is done by maximizing sources of tax revenue and seeking new potential as sources of tax revenue (Putry, 2011).

PAD is one source of regional revenue that reflects the success of implementing regional autonomy. One of the requirements for the implementation of regional autonomy is that regions are required to meet their regional fiscal needs. The matter leads to greater, more real and responsible regional autonomy (Darise, 2009).

The higher the amount of PAD revenue and the more $\mathrm{PAD}$ contributes to regional revenue, the good the regional government's financial performance (Safitri, 2015). The data in this study show that PAD revenue is inversely proportional to the balancing fund in each region. The balancing fund is the highest regional revenue while PAD is the lowest regional revenue. PAD as an instrument of regional revenue can reflect regional financial performance in Lampung Province, with the following data:

Table 1. Characteristics of Regencies/Cities in Lampung Province

\begin{tabular}{|c|c|c|c|c|c|c|}
\hline No & County/City & $\begin{array}{l}\text { PAD } \\
\text { (The year 2019) }\end{array}$ & $\begin{array}{l}\text { Balancing Fund } \\
\text { (the Year 2019) }\end{array}$ & $\begin{array}{l}\text { HDI } \\
\text { (The } \\
\text { year } \\
\text { 2019) }\end{array}$ & $\begin{array}{l}\text { Population } \\
\text { *thousand } \\
\text { (The year } \\
\text { 2019) }\end{array}$ & $\begin{array}{l}\text { GDP } \\
\text { *percent } \\
\text { (The } \\
\text { year } \\
\text { 2019) }\end{array}$ \\
\hline 1 & $\begin{array}{l}\text { Regency. } \\
\text { Lampung }\end{array}$ & $193,634,175,310$ & $1,797,258,034,498$ & 70.16 & 1281.31 & $5 \cdot 35$ \\
\hline 2 & Regency. South Lampung & $275,464,317,224$ & $1,398,455,089,730$ & 68.22 & 1011.29 & 5.13 \\
\hline 3 & Regency. Tanggamus & $76,050,778,580$ & $1,131,249,311,788$ & 66.37 & 598,30 & 5.02 \\
\hline 4 & Regency. West Lampung & $65,267,416,665$ & $791,712,917,260$ & 67.50 & 302.83 & 5.19 \\
\hline 5 & Regency. Onion Bones & $82,379,613,623$ & $823,127 \cdot 374,731$ & 68.23 & 450.90 & 5.41 \\
\hline 6 & $\begin{array}{ll}\text { Regency. } & \text { central } \\
\text { Lampung } & \\
\end{array}$ & $193,634,175,310$ & $1,797,258,034,498$ & 70.16 & 1281.31 & $5 \cdot 35$ \\
\hline 7 & Regency. East Lampung & $147,527,535,828$ & $1,475,128,391,944$ & 69.34 & $1044 \cdot 32$ & 3.81 \\
\hline 8 & Regency. Right Way & $62,353,560,984$ & $990,355,064,471$ & 67.19 & 450.11 & 5.17 \\
\hline 9 & Bandar Lampung & $627,296,544,827$ & 1.400 .623 .202 .255 & $77 \cdot 33$ & 1051.50 & 6.21 \\
\hline 10 & Metro City & $176,199,324,166$ & $641,899,006,676$ & 76.77 & 167.41 & 5.58 \\
\hline 11 & Regency. Pringsewu & $86,313,480,516$ & $859,198,408,361$ & 69.97 & 400,19 & 5.04 \\
\hline 12 & Regency. Offer & $65,693,842,719$ & $895,181,485,501$ & $65 \cdot 75$ & $444 \cdot 38$ & 5.00 \\
\hline 13 & Regency. Mesuji & $45,620,663,052$ & 632.875 .492 .470 & 63.52 & 200,20 & 5.26 \\
\hline 14 & Regency. West Coast & $29,323,369,726$ & $587,653,782,034$ & 63.79 & 154.90 & $5 \cdot 37$ \\
\hline 15 & $\begin{array}{l}\text { Regency. West Onion } \\
\text { Bone }\end{array}$ & $32,410,517,401$ & $674,827,807,842$ & 65.93 & 273.22 & $5 \cdot 36$ \\
\hline
\end{tabular}

Source: Processed by researchers sourced from BPS Lampung Province, 2020 
The financial performance of regional governments is a potential that exists in the regions to utilize sources that can support PAD revenues for the functioning of the government system, services to the community and regional development without being completely dependent on the central government (Rahmawati et al., 2016). It is the same as the area in Lampung Province.

Regions in Lampung Province have high regional revenue but are not followed by high PAD. As well as PAD revenue, the effectiveness of PAD and the level of PAD contribution given to regional revenue in the districts/cities will be studied in this research, namely Pringsewu Regency, Mesuji Regency, and Bandar Lampung City.

These are some things that cause each region has different $P A D$ between urban (city), sub-urban (buffer) and rural (rural) areas. The difference in PAD is due to the different levels of community mobility in the new autonomous regions, especially Pringsewu Regency, Mesuji Regency, and Bandar Lampung City. The number of residents affects the level of PAD acceptance (Asmuruf et al., 2015). This difference is the basis for researchers to analyze the level of effectiveness of PAD and its PAD effectivity to the amount of its contribution to regional revenue. The differences in the characteristics of each region cause the differences in $P A D$ revenues, the effectiveness of $\mathrm{PAD}$ receipts affects the number of regional revenue contributions.

Effectiveness is a condition of achieving the expected or desired goals by realizing the completion of the work by the planned plan (Mardiasmo, 2011). Efforts to determine the effectiveness of Pringsewu Regency PAD, Bandar Lampung City and Mesuji Regency can be seen from how the City/Regency achieves the existing PAD targets. Sources of PAD revenue are levies, other legitimate PAD, taxes, and the results of separated regional wealth management.
It can be known by comparing the realization and target of PAD.

Regional financial independence is the ability of regional governments to obtain and manage regional finances for government activities, namely for development and services to the community, to prosper the community. The main sources of PAD revenue are retribution and regional taxes; these two sources of revenue play a role in the framework of regional autonomy (Kori, 2001). Can reflect regional financial independence by realizing $\mathrm{PAD}$ receipts compared to revenue from other sources such as regional loans and central government assistance (Halim, 2004).

In this study, there are several references to previous studies related to the effectiveness of PAD. The first study by Yaneka Julastiana and Wayan Suartana entitle Analysis of Efficiency and Effectiveness of Regional Original Revenue of Klungkung Regency. The results showed that the efficiency level of regional tax and retribution revenue in Klungkung Regency in 2005-2011 was classified as efficient, with an average ratio of $70.97 \%$. The level of effectiveness of regional levies and tax revenues in Klungkung Regency in 20052011 is classified as very effective, with an average ratio of $112.36 \%$ (Julastiana et al., 2012).

The second study by Asnariza, Abubakar Hamzah, Nur Syechalad (2014) entitle Analysis of the Efficiency and Effectiveness of Collecting Regional Revenue in the City of Sabang. The results in the study are PAD levies in Sabang City are more efficient every year with smaller expenses. The PAD levy in Sabang City is effectively carried out every year with a target achievement rate of more than $100 \%$. Except in 2005, the PAD levy has not been effectively carried out. Economic development impacts increasing PAD revenue in Sabang City with a positive elasticity coefficient value above $1 \%$, except for 2009 with negative results and 
more than $1 \%$, which means that economic development impacts decreasing PAD revenue (Asnariza et al., 2014).

The third study by Gusti Ayu Sonia Wina Laksmi and Ni Luh Supadmi (2014) entitle the Effectiveness of Collecting Regional Revenue and the Contribution of PAD to Regional Revenue. The result is that the level of financial independence of the Sumbawa Regency is very low. The average level of effectiveness of PAD in 2010-2012 is classified as less effective, and the average level of regional financial efficiency in the Sumbawa Regency is classified as inefficient. Then, the average PAD growth rate shows positive growth. The largest contribution to the largest contribution to regional spending is occupied by indirect spending, while regional revenue is occupied by balancing funds (Laksmi et al., 2014).

Based on previous research references that have been reviewed regarding the effectiveness of PAD. This study is different from the results of previous research references since the previous research references did not discuss the level of effectiveness of PAD and the contribution of PAD to regional revenue. This study's effectiveness level illustrates the diversity of PAD receipts each year, both decreasing and increasing PAD received. The PAD data used was 2016-2019, so within the last four years, it will describe the level of regional effectiveness.

Some reasons above make researchers interested in conducting this study. The study that the researcher conducted is to determine the level of effectiveness of PAD and the influence of PAD in the contribution to regional revenue in Pringsewu Regency, Mesuji Regency, and Bandar Lampung City. This study's effectiveness level is a variation of the existing effectiveness criteria in PAD acceptance according to the effectiveness criteria that the researchers used to analyze the effectiveness of PAD receipts.
Hence the objective of this study is to determine the level of effectiveness of PAD and the influence of PAD in contributing to regional revenue.

Researchers conducted this study in Pringsewu Regency, Bandar Lampung City, and Mesuji Regency. Bandar Lampung City represents urban characteristics, while Pringsewu Regency and Mesuji Regency represent the new autonomous region characteristics in Lampung Province. Chose Pringsewu Regency, Mesuji Regency, and Bandar Lampung City with the consideration of evaluating the effectiveness of PAD and the contribution of PAD to regional revenue for the last four years.

\section{RESEARCH METHOD}

Descriptive research with a quantitative approach was chosen as the method in analyzing the problems in this study. Carried out Descriptive research with a quantitative approach since an assessment of the effectiveness of PAD and the contribution of PAD to regional revenue requires statistical data or was calculated using a number system. Numerical data were used as an aid to analyze the problems about the object of the study. Numbers as a tool in concluding or, in other words, numerical data were only used as material for analysis of the results of calculations. Quantitative descriptive does not test the hypothesis but explains the variables studied (Arikunto, 2005).

The data used in this study were sourced from secondary data, so that this study used a secondary data analysis (ADS) approach. The secondary data used in this research were the Bandar Lampung City Budget Report 2016-2019, Pringsewu Regency APBD Report 2016-2019, and Mesuji Regency APBD Report 2016-2019. The data were analyzed using the effectiveness ratio formula according to Halim (2004): 


$$
\begin{aligned}
& \text { Ratio of Effectiveness } \\
& \quad=\frac{\text { Realization } P A D(r P A D)}{\text { Target } P A D(t P A D)} \times 100 \%
\end{aligned}
$$

The PAD effectiveness ratio produced can be categorized as effective if the realization is greater than the PAD target. The criteria for evaluating the effectiveness of PAD receipts are by the Decree of the Minister of Home Affairs Number $690,900,327$ of 1996 , namely:

Table. 2 Criteria for Effectiveness Level of Financial Performance

\begin{tabular}{ll}
\hline Effectiveness Criteria & Financial Performance Ratio \\
\hline Ineffective & Less than $60 \%$ \\
Less effective & $60 \%-80 \%$ \\
Effective enough & $80 \%-90 \%$ \\
Effective & $90 \%-100 \%$ \\
Very effective & Above $100 \%$ \\
\hline
\end{tabular}

Source: Financial Performance Assessment Guidelines

Can do it the way to analyze the contribution of PAD to Regional Revenue by calculating the following formula:

Contribution $=\frac{\text { Reallization of Regional Revenue }}{\text { Total } P A D} \times 100 \%$

The results of the calculation by comparing the realization of regional revenue and total $\mathrm{PAD}$ can be analyzed with the criteria for assessing the contribution of PAD to regional revenue, according to the Research Team for Development of the Ministry of Home Affairs (Litbang Kemendagri) \& Fisipol UGM can be seen in table 3 .

Table. 3 Categories of Contribution Assessment

\begin{tabular}{ll}
\hline Contribution Criteria & Contribution \\
\hline Very less & Less than $10 \%$ \\
Currently & $20.10 \%-30.00 \%$ \\
Pretty good & $30.10 \%-40.00 \%$ \\
Well & $40.10 \%-50.00 \%$ \\
Very good & above $50 \%$ \\
\hline
\end{tabular}

Source: Research and Development Team of the Ministry of Home Affairs, Faculty of Social and Political Sciences UGM
RESULTS AND DISCUSSION

Effectiveness of PAD in Bandar Lampung City, Pringsewu Regency and Mesuji Regency

\section{2016-2019 Bandar Lampung City}

Between 2016 and 2019, the effectiveness ratio or PAD effectiveness ratio of Bandar Lampung City was the highest in 2017 and the lowest in 2018. The effectiveness ratio of Bandar Lampung City in 2016-2019 was at an average value of $73.46 \%$ and categorized as the criteria of less effective as described in table 4.

Table 4. Effectiveness Ratio of PAD in Bandar Lampung City in 2016-2019

\begin{tabular}{lccc}
\hline Year & Realization & Target & $\begin{array}{c}\text { Results } \\
(\%)\end{array}$ \\
\hline 2016 & 483.379 .075 .538 & $689,276,566,561$ & $70.13 \%$ \\
2017 & 612.809 .680 .625 & $779,276,566,600$ & $78.64 \%$ \\
2018 & $550,275,048,131$ & $788,377,674,850$ & $69.80 \%$ \\
2019 & $627,296,544,826$ & $833,434,356,250$ & $75.27 \%$ \\
Average & & $73.46 \%$ \\
\hline
\end{tabular}

Source: Processed by Researchers (2021)

Based on table 4, the lowest effectiveness ratio is in 2018 with a less effective category with a value of $69.80 \%$ and the highest in 2017 with a less effective category with a value of $78.64 \%$. It occurred due to several existing factors, such as the realization of several sources of PAD revenue that was greater than other sources of revenue, even in 2017, which was classified as larger in the last four years, only having two sources of PAD revenue which the realization was greater or by the target set has been determined, namely from the source of revenue tax revenue, other legitimate PAD and separated regional wealth management. However, in the following year, namely in 2018 , there was only one source of PAD revenue whose realization was included in the effective criteria, namely the results of separated regional wealth management but did not make PAD revenue effective. For that year it was classified in the less effective category and became the lowest in 4 years. Final. 
Overall sources of PAD revenue fluctuate, such as regional levies, other legitimate $\mathrm{PAD}$, regional taxes and the results of separated regional wealth management so that they affect PAD revenue. Based on it, the source of PAD revenue described poor performance. When viewed as a whole from the classification of the effectiveness level of PAD, the effectiveness of PAD in Bandar Lampung City fluctuated or up and down. Still, in the last four years, it has always been classified into the less effective category. PAD contribution to regional revenue is as in the explanation of table 5 .

Table 5. Contribution of PAD to Bandar Lampung City Regional Revenue in 2016-2019

\begin{tabular}{lccc}
\hline Year & $\begin{array}{c}\text { Realization of } \\
\text { PAD }\end{array}$ & $\begin{array}{c}\text { Regional } \\
\text { Revenue }\end{array}$ & $\begin{array}{c}\text { Results } \\
(\%)\end{array}$ \\
\hline 2016 & 483.379 .075 .538 & $2,057,083,146,727$ & 23.49 \\
2017 & 612.809 .680 .625 & $2,081,420,040,686$ & 29.44 \\
2018 & $550,275,048,131$ & $2,162,096,665,250$ & 25.45 \\
2019 & $627,296,544,826$ & $2,294,656.383,146$ & 27.33 \\
Average & & 26.42 \\
\hline
\end{tabular}

Source: Processed by Researchers (2021)

The lack of success of Bandar Lampung City in realizing the existing PAD targets and the lack of success had always made Bandar Lampung in the last four years have a level of PAD effectiveness, which was considered less effective. The less effective category did not reflect the low contribution to Pringsewu Regency's regional revenue. The amount of existing PAD realization was very different from other sources of regional revenue. Include the amount of PAD realization in the effective criteria, but the contribution to regional revenue was quite large; the average contribution of PAD to regional revenue was at a ratio of $26.42 \%$, which is included in the moderate contribution criteria table. Bandar Lampung City was dependent on balancing funds or transferring funds to the regions, which reflects a minus fiscal gap. However, the contribution of PAD to regional revenue is in the medium category. Fiscal capacity was the ability of regional governments to collect revenues based on the sources they have. The low fiscal capacity was caused by the inability of the regions to collect regional revenue sources. Bandar Lampung City had a financial need that was not proportional to its fiscal capacity. It has a level of dependence on balancing or transferring funds to the region, reflecting a minus fiscal gap. Fiscal capacity was the ability of regional governments to collect revenues based on the sources they have. The low fiscal capacity was caused by the inability of the regions to collect regional revenue sources. Bandar Lampung City has a fiscal need that is not proportional to its fiscal capacity. It has a level of dependence on balancing or transferring funds to the region, reflecting a minus fiscal gap.

\section{2016-2019 Pringsewu Regency}

Between 2016 and 2019, Pringsewu Regency's effectiveness ratio or PAD effectiveness level was the highest in 2017 and the lowest in 2018. The Pringsewu Regency's 2016-2019 effectiveness ratio was at an average value of $108.21 \%$ and classified into the very effective criteria; however, from 2016 to 2019, none were classified as less effective as described in the table 6 .

Table 6. PAD Sewu Regency's PAD Effectiveness Ratio in 2016-2019

\begin{tabular}{llcc}
\hline Year & \multicolumn{1}{c}{ Realization } & Target & $\begin{array}{c}\text { Results } \\
(\%)\end{array}$ \\
\hline 2016 & $68,157,777,766$ & $70,600,000,000$ & 96.54 \\
2017 & $117,629,412,764$ & $77,798,900,000$ & 151.19 \\
2018 & 71.824 .582 .142 & $82,534,500,000$ & 87.02 \\
2019 & $86,313,480,516$ & $87,997,304,000$ & 98.09 \\
Average & & 108.21 \\
\hline
\end{tabular}

Source: Processed by Researchers (2021)

Based on table 6, the lowest effectiveness ratio was in 2018 with a moderately effective category with a value of $87.02 \%$ and the highest in 2017 with a very effective category with $151.19 \%$. It occurred due to several existing factors, such as the realization of several sources of PAD revenue that was greater than other sources of revenue, even in 2017, which 
was classified as very effective, only having two sources of PAD revenue, the realization of which was greater or by the set targets. The largest source of PAD revenue is from tax revenues and other legitimate PAD. The following year, in 2018, there were two sources of PAD revenue whose realization was greater than or by the existing target.

Overall sources of PAD revenue fluctuate, such as regional levies, separated regional wealth management results, and other legitimate PAD. Only sources of revenue originating from regional taxes had been consistently in the last four years, namely 2016-2019, which have always been in the effective category. Based on it, the source of PAD revenue originating from regional taxes always illustrated good performance. When viewed as a whole from the classification of the effectiveness level of PAD, the effectiveness level of PAD in Pringsewu Regency fluctuated or up and down but was never classified as less effective. The contribution of PAD to regional revenue is as described in table 7 .

\begin{tabular}{|c|c|c|c|}
\hline \multicolumn{4}{|c|}{$\begin{array}{c}\text { Table 7. Contribution of PAD to Regional } \\
\text { Revenue of Pringsewu Regency in 2016-2019 }\end{array}$} \\
\hline Year & $\begin{array}{l}\text { Realization of } \\
\text { PAD }\end{array}$ & $\begin{array}{l}\text { Regional } \\
\text { Revenue }\end{array}$ & $\begin{array}{l}\text { Results } \\
(\%)\end{array}$ \\
\hline 2016 & $68,157,777,766$ & $1,122,575,387,671$ & 6.07 \\
\hline 2017 & $117,629,412,764$ & $1,194,493,674,541$ & 9.84 \\
\hline 2018 & 71.824.582.142 & $1,150,545,601,855$ & 6.24 \\
\hline 2019 & $86,313,480,516$ & $1,206,214,223.949$ & 7.15 \\
\hline \multicolumn{3}{|c|}{ Average } & 7.32 \\
\hline
\end{tabular}

Source: Processed by Researchers (2021)

The success of the Pringsewu Regency in realizing the existing PAD targets always made Pringsewu Regency have a relatively effective PAD effectiveness level. The effective category did not reflect a high contribution to Pringsewu Regency's regional revenue. The amount of existing PAD realization was very different from other sources of regional revenue. The total contribution of PAD to regional revenue was never greater than $10.00 \%$. It caused the ratio of PAD contribution to regional revenue to be included in the very low criteria and made Pringsewu Regency have a level of dependence on balancing funds or transfer funds to the regions, which reflected a minus fiscal gap. Fiscal capacity was the ability of regional governments to collect revenues based on the sources they have. The low fiscal capacity was caused by the inability of the regions to collect regional revenue sources. Pringsewu Regency has fiscal needs that are not proportional to its fiscal capacity. It has a level of dependence on balancing or transferring funds to the region, reflecting a minus fiscal gap.

\section{2016-2019 Mesuji Regency}

The effectiveness level of Mesuji Regency's PAD between 2016 and 2019 has the highest effectiveness ratio, namely in 2019 and the lowest in 2017. Mesuji Regency's PAD effectiveness ratio from 2016 to 2019 is at an average value of $89.00 \%$ and belongs to the criteria quite effective, as in the explanation of table 8.

Table 8. Effectiveness Ratio of PAD in Mesuji Regency 2016-2019

\begin{tabular}{cccc} 
Year & Realization & Target & $\begin{array}{c}\text { Results } \\
(\%)\end{array}$ \\
\hline 2016 & $27,783,046,527$ & $28,718,079.000$ & 96.73 \\
2017 & $22,114,016,973$ & $36,224,899.000$ & 61.05 \\
2018 & $33,206,360,523$ & $41,025,735,777$ & 80.94 \\
2019 & $38,896,476,000$ & $45,620.663 .052$ & 117.29 \\
Average & \multicolumn{3}{c}{89.00} \\
\hline \multicolumn{3}{c}{ Source: Processed by Researchers (2021) }
\end{tabular}

Based on table 8, the average effectiveness ratio is categorized as quite effective and higher in 2019 with a value of $117.29 \%$ is classified as a very effective category, while the lower in 2017, with a value of $61.05 \%$, belongs to the less effective category. Effective. Overall the PAD revenue effectiveness ratio always increases and decreases, it is because there are several realizations of revenue sources that are inconsistent and always fluctuate with increases and decreases.

The source of PAD revenue from regional taxes, which is always consistent with its revenue, is in the very effective 
category in the last four years except in 2016, which is quite effective. In contrast to the source of PAD revenue from levies and regional taxes, the revenue is always consistent, which is never in the effective category and always in the effective category and has reached the lowest point in 2017 with a value of $12.43 \%$ belonging to the ineffective category.

Overall, PAD revenue sourced from regional taxes illustrates good performance. The results of separated regional wealth management and other legitimate PAD with ever-changing movements illustrate good performance when both sources are good and vice versa. Then the regional retribution illustrates the poor performance. Overall, the average level of effectiveness of PAD receipts is classified as quite effective. PAD's contribution to regional revenue is as in the explanation in table 9 .

Table 9. Contribution of PAD to Regional Revenue of Mesuji Regency in 2016-2019

\begin{tabular}{lccc}
\hline Year & $\begin{array}{c}\text { Realization of } \\
\text { PAD }\end{array}$ & $\begin{array}{c}\text { Regional } \\
\text { Revenue }\end{array}$ & $\begin{array}{c}\text { Results } \\
(\%)\end{array}$ \\
\hline 2016 & $27,783,046,527$ & $729,683,759,773$ & 3.80 \\
2017 & $22,114,016,973$ & $748,639,366,528$ & 2.95 \\
2018 & $33,206,360,523$ & $844,392,798,396$ & 3.93 \\
2019 & $38,896,476,000$ & $895,064,937,674$ & 5.09 \\
Average & & 3.94 \\
\hline
\end{tabular}

Source: Processed by Researchers (2021)

The success of Mesuji Regency in realizing the existing PAD targets, this success always makes Mesuji Regency have a relatively effective level of PAD effectiveness. The quite effective category does not reflect a high contribution to the regional revenue of Mesuji Regency since the amount of PAD realization that exists is very different from other sources of regional revenue. With the total contribution of PAD to regional revenue, which is never greater than $6 \%$. It causes the ratio of the contribution of PAD to regional revenue to be included in the very low criteria and makes Mesuji Regency have a level of dependence on balancing funds or transfer funds to the regions, which reflects a minus fiscal gap. Fiscal capacity is the ability of regional governments to collect revenues based on the sources they have. The low fiscal capacity was caused by the inability of the regions to collect regional revenue sources. Mesuji Regency has fiscal needs that are not proportional to its fiscal capacity. It has a level of dependence on balancing or transferring funds to the region, reflecting a minus fiscal gap.

\section{CONCLUSION}

The effectiveness level of PAD in Pringsewu Regency, Mesuji Regency, and Bandar Lampung City have an unstable PAD since it has increased and decreased. It indicates that the level of effectiveness of the existing PAD does not have a major impact on the contribution of PAD to regional revenue. Bandar Lampung City, Pringsewu Regency, and Mesuji Regency in 2016-2019 were volatile; there was an increase and decrease in the effectiveness of the PAD owned by each region. Pringsewu and Mesuji districts have had an average PAD effectiveness ratio in the last four years, including the effective category. For Bandar Lampung City in the last four years, included in the less effective category, but the contribution of PAD to regional revenue was much greater.

\section{REFERENCES}

Arikunto, S. (2005). Research Management. Jakarta: Arikunto, S. (2005). Manajemen Penelitian. Jakarta: Rineka Cipta. HIm 26

Asmuruf, M.F., Rumate, V.A., Kawung, G.M.V. (2015). Pengaruh Pendapatan Dan Jumlah Penduduk Terhadap Pendapatan Asli Daerah ( PAD ) Di Kota Sorong. Jurnal Berkala Ilmiah, 15 (5): 727-737.

Asnariza., Hamzah, A., dan Syechalad, N. (2014). Analisis Efesiensi dan Efektivitas Pemungutan Pendapatan Asli Daerah Kota Sabang. Jurnal Ilmu Ekonomi, 2 (4), hlm 7785.

Badan Pusat Statistik Provinsi Lampung. (2019). Provinsi Lampung Dalam Angka 2019. Bandar Lampung: Badan Pusat Statistik. Hlm 1-603 
Darise, N. (2009). Pengelolaan Keuangan Daerah Edisi Kedua. Jakarta: PT Indeks. HIm 48

Halim, A. (2004). Manajemen Keuangan Daerah (Edisi Revisi). Yogyakarta: UPP AMP YKPN. HIm 129

Julastiana, Y., dan Suartana, I.W. (2012). Analisis Efisiensi dan Efektivitas Penerimaan Pendapatan Asli Daerah Kabupaten Klungkung. Jurnal Universitas Udayana. HIm $1-17$

Kori, E. (2001). Peranan Pajak Daerah dan Retribusi Daerah dalam Rangka Otonomi Daerah di Kota Bengkulu. Tesis. Yogyakarta: UGM.

Laksmi, G.A.S.W., dan Supadmi, N.L. (2014). Efektivitas Pemungutan Pendapatan Asli Daerah dan Kontribusi PAD pada Pendapatan Daerah. Jurnal E-Akuntansi Udayana, 9 (2): 515-524
Mardiasmo. (2011). Perpajakan, Edisi Revisi 2011. Yogyakarta: Andi. HIm 1

Putry, N., dan Abdullah. (2011). Jurnal Peranan Pajak Daerah dan Retribusi Daerah di Kota Bengkulu. Jurnal Akutansi, 1 (3): 268-287

Rahmawati, N.K.E., dan Putra, I.W. (2016). Jurnal Analisis Kinerja Keuangan Pemerintah Kabupaten Sumbawa Tahun Anggaran 20102012. E-Jurnal Akuntansi, XV (3): 1767-1795.

Rahmayati, A. (2016). Analisis Kinerja Keuangan Pemerintah Daerah Kabupaten Sukoharjo Tahun Anggaran 2011-2013. Jurnal Eka Cida, 1 (1): 40-54.

Safitri, M.L.E. (2015). Analisis Efektivitas Pencapaian Target Pendapatan Asli Daerah. Jurnal Akuntansi \& Keuangan, 6 (2): 137-149

Sriyana, J. (2009). Analisis Kapasitas Fiskal Daerah: Studi Kasus di Kabupaten Gunung Kidul. Jurnal Unisia, XXXII (72): 209-227 